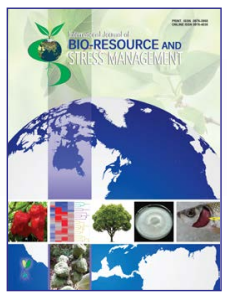

\title{
Management of Light for Quality Production of Litchi
}

\author{
Sushil Kumar Purbey ${ }^{1}$, Sanjay Kumar Singh ${ }^{2}$ and Alemwati Pongener ${ }^{2}$ \\ ${ }^{1}$ ICAR-MGIFRI, Motihari, Bihar (845 429), India \\ ${ }^{2}$ ICAR-NRC on Litchi, Muzaffarpur, Bihar (842 002), India
}

6 Open Access Corresponding Author

Sushil Kumar Purbey e-mail: skpurbey_nrcl@yahoo.com

Citation: Purbey et al., 2019. Management of Light for Quality Production of Litchi. International Journal of Bio-resource and Stress Management 2019, 10(5):529-538. HTTPS://DOI.ORG/10.23910/ IJBSM/2019.10.5.2034

Copyright: (c) 2019 Purbey et al. This is an open access article that permits unrestricted use, distribution and reproduction in any medium after the author(s) and source are credited.

Data Availability Statement: Legal restrictions are imposed on the public sharing of raw data. However, authors have full right to transfer or share the data in raw form upon request subject to either meeting the conditions of the original consents and the original research study. Further, access of data needs to meet whether the user complies with the ethical and legal obligations as data controllers to allow for secondary use of the data outside of the original study.

Conflict of interests: The authors have declared that no conflict of interest exists.

Acknowledgement: This work was supported by ICARNRC on Litchi, Muzaffarpur, Bihar.

\begin{abstract}
Light is prerequisite for plant growth and production of quality fruit. Management of different aspects of light viz. quantity, quality and duration promises to provide a new technological alternative to sustainable production of horticultural crops. Litchi is very sensitive to climatic aberrations. The growth, panicle emergence time, flowering behavior, yield and quality of fruits have been found to be influenced by the impact of climate change. Under changing climatic conditions and consumer's demand, light can be managed by pruning and training, bagging of fruit bunches, use of photo-selective shade nets and reflective films in orchards. These concepts, involved in optimization of light quantity and quality, have significant effect on the litchi tree responses and practically feasible tools for sustainable management of yield and quality in modern litchi orchards. Canopy management in litchi improves the ability of sunlight to penetrate the tree, enhances the colour of fruit and improves quality. Pruning resulted in increased photosynthetic efficiency of litchi plants due to improved light penetration inside the trees. Similarly bagging of fruit bunches and use of shade net has been reported to produce more class-I fruit by reducing incidences of sun-burn and cracking of fruits. This review attempts to bring together research on effect of light on fruit quality and how manipulation of light can be achieved through different practices in the orchard towards quality fruit production under changing climatic conditions.
\end{abstract}

Keywords: Litchi, light, environment, quality, fruit

\section{Introduction}

The quality production of fruits is an astonishingly complex process that depends on a wide variety of factors viz. weather, soil, insect-pests and diseases, and orchard management) and their interaction effects. Among all these factors light is one of the most important factors that directly or indirectly affect production of good quality fruit. Global climate change has aggravated this situation where, during the last 5 decades, average annual temperatures have risen by around 0.48 degrees and average monsoon rainfall has declined by $26 \mathrm{~mm}$ (IPCC, 2018). There has been a steady increase in direct solar radiation, temperature extremities and rainfall distribution. Beside, the changes in paradigm of efficiency of old orchard system and introduction of high density planting have compelled for requirement of more technological innovation for adequate climate management in fruit trees (Palmer, 2011; Blanke, 2011). Growers have little control over these climatic factors especially on amount, duration

\section{Article History}

RECEIVED in $08^{\text {nd }}$ September 2019 RECEIVED in revised form $25^{\text {th }}$ October 2019 ACCEPTED in final form $30^{\text {th }}$ October 2019 
and quality of light. Therefore, optimizing sunlight use can be achieved in orchard systems through development in cultural practices such as pruning, training system, tree arrangement, and orchard design, directed toward the improvement of "quantity of light" (i.e. the amount of photosynthetically active radiation, PAR) intercepted and distributed by orchards (Jackson, 1980 and Palmer, 1989). However, alongside the PAR quantity that provide the energy and carbon needed for sustained tree and fruit growth, plant growth and development also respond to subtle changes in the light quality (i.e. spectral composition of sunlight). Supplementary lighting does offer opportunity to increase yield during low light periods, but is generally considered commercially unprofitable. The other means for manipulating light are limited to screening or shading and are employed when light intensities are too high. Fruit plants respond to light quantity, quality, direction, and periodicity. There are numerous photoreceptors in plants, including chlorophylls, phtyochromes, cryptochromes, phototropins, and ones that react to green light (Batschauer, 1999; Folta and Maruhnich, 2007). Efforts to manipulate plant morphology and physiology using photoselective filters have been ongoing for decades, especially in greenhouse environments (Cerny et al., 2003; Ilias and Rajapakse, 2005; Kambalapally and Rajapakse, 1998; Li et al., 2010). These can be also utilized in fruit crops in field to harness the light towards quality fruit production.

The litchi (Litchi chinensis Sonn.) is one of the least adaptable of tropical and subtropical fruit crops, which flowers and fruits satisfactorily only under consistent favourable climatic conditions and dry winter (Menzel, 1983). Menzel and Simpson (1988) demonstrated that moderate day/night temperatures $\left(20^{\circ} / 15^{\circ}\right.$ v. $\left.15 / 10{ }^{\circ} \mathrm{C}\right)$ increased vegetative growth and reduced flowering in the seven litchi cvs Tai So, Bengal, Souey Tung, Kwai May Pink, Kwai May Red, Salathiel and Wai Chee. At higher temperatures (25/20 and $30 / 25^{\circ} \mathrm{C}$ ), vegetative growth was promoted further and flowering eliminated. Temperature also influenced the type of inflorescence formed. More leaves were formed on the panicles of trees growing at $20 / 15^{\circ}$ than at $15 / 10^{\circ} \mathrm{C}$. Similarly, Batein and Lahav (1981) grew three litchi cvs Kwai May, Haak Yip and Bengal in controlled temperature glasshouses maintained at constant temperatures between $10^{\circ}$ and $35{ }^{\circ} \mathrm{C}$. The plants grew best vegetatively at $30{ }^{\circ} \mathrm{C}$, ceased growth below $15^{\circ}$, but flowered only at $10^{\circ} \mathrm{C}$. Litchi requires a frost-free environment. Winter and autumn temperature between $8^{\circ} \mathrm{C}$ and $13{ }^{\circ} \mathrm{C}$ for about 200 hours coupled with moisture deficit induce profuse flowering. Recent work also support that the stability of the light-activated states of phytochromes and phototropins is prolonged at lower temperatures through retardation of dark reversion as these photo receptors functions as thermal timers that integrate temperature information over the course of the night (Jung et al., 2016; Legris, et al. 2016 and Fujii et al., 2017). Areas with winter temperature above $25{ }^{\circ} \mathrm{C}$ are not suitable for litchi cultivation. Temperatures below $2{ }^{\circ} \mathrm{C}$ damage new leaves and those below $-2{ }^{\circ} \mathrm{C}$ can kill trees (Menzel and Waite 2005). For such a climatic sensitive crop, the changing climatic condition have adverse effects leading to irregular panicle immergence, poor fruit set, heavy fruit drop, poor colour development and overall poor fruit quality. Kumar (2015) observed and reported that there is poor as well as erratic bearing pattern in trees in many important litchigrowing areas of India. The growth, panicle emergence time, flowering behaviour and flowering phase have been found to be influenced by the impact of climatic change. The productivity, yield and quality fruit production have also been found to be very much affected by environmental parameters like temperature, photoperiod/ light intensity, moisture content in the soil and humidity in the atmosphere (Kumar and Nath, 2012).

In India, fruit development of litchi coincides with rising atmospheric temperature, low soil moisture and relative humidity accompanied with high solar radiation particularly of UV and far red radiation that constitute conditions for skin burning and cracking (Yadav et al., 2011, Purbey and Kumar, 2015). However, if the leaves or fruit are exposed to harmful ultraviolet radiation or they accumulate too much light radiation, damage to cells and tissues occurs. If not repaired, this tissue damage eventually leads to cell/tissue death, which is a common physiological disorder called sunburn. Temperature higher than $38^{\circ} \mathrm{C}$ in combination with relative humidity lower than $50 \%$ and high solar radiation was very favourable for cracking of litchi that causes $10-25 \%$ crop loss (Mitra et al., 2014). Under such conditions, this review is an attempt to unravel the underlying mechanisms of light towards quality production of litchi fruits. Although quantity and quality of light have proven to be the major meteorological factors affecting performance of many crop plants, few studies focusing on how management of light influences the production of litchi, which is much more vulnerable to climate change, have been discussed here.

\section{Role of Light}

Photoautotrophic higher plants are dependent on light for survival (Smith, 1982). Light is perhaps the most important consideration for optimizing plant growth, with light being utilized as both an energy source and as a developmental signal. All aspects of plant development are responsive to light, from germination through to the transition to flowering and fruit ripening (Fankhauser and Chory, 1997). The process by which developmental alterations occur in response to the changing light environment is referred to as photomorphogenesis (Whitelam and Halliday, 2007). The three aspects of light viz. light intensity, duration, and spectral quality influence a range of vegetative characteristics including branching, internode elongation, leaf expansion, and orientation, with each of the photoreceptor families contributing via the photosensory network (Whitelam and Halliday, 2007 and Leduc et al., 2014). Light is also a fundamental signal necessary for the transition to flowering (Whitelam and Halliday, 2007), while the effects 
of light upon fruit development are also beginning to emerge. Between 1 and 2\% of the solar radiation falling on Earth's surface is used by plants to fix $\mathrm{CO}_{2}$ in photosynthesis (Turner, 1994). The amount of $\mathrm{CO}_{2}$ fixed by a tree depends on the distribution of light through the canopy and the physiology of the leaves, especially their nitrogen content. Several studies have investigated the photosynthetic responses of tropical tree seedlings to changes in solar radiation (Thompson et al., 1988, Ramos and Grace, 1990, Riddoch et al., 1991, Wiebel et al., 1993, Eschenbach et al., 1998). For example, Riddoch et al.(1991) reported that photosynthesis in Naucleadiderrichi Merrill, a West African pioneer tree, was saturated at a photosynthetic photon flux density (PPFD) of $1000 \mu \mathrm{mol} \mathrm{m}{ }^{-2}$ $\mathrm{s}^{-1}$, whereas in the climax species, Entandrophragmaangolense (Welw.) C. DC., photosynthesis saturated at a PPFD of 300 $\mu \mathrm{mol} \mathrm{m} \mathrm{m}^{-2} \mathrm{~s}^{-1}$. Seedlings of the climax species presumably fixed significant amounts of $\mathrm{CO}_{2}$ at PPFDs commonly found in small gaps in the forest understory. Fruit plant respond to light of varying intensity at different stages of growth and development phases. Likewise, Carbon exchange rate (CER) is strongly dependent on irradiance, absorption and utilization of photon energy. Low irradiance causes insufficient light penetration into canopy influencing CER directly by reducing photon energy utilization, thus decreasing productivity. (Kumar and Kumar, 2016).

Light is an important factor in production of fruit. It has a role in flower induction as well as in fruit development through carbohydrate synthesis. While increased assimilates in the shoots is a pre-requisite for flowering in mango and other fruits generally, high yield of quality fruits are attributed to high light interception and distribution in the tree canopy (Cerny et al., 2003). Fruit quality is typically dependent upon the health of the bearing plants, although direct light irradiation also alters their biochemical composition (Zoratti et al., 2014). One of the principle determinants of fruit quality is the accumulation of phenylpropanoids (including flavonols, anthocyanins, and proanthocyanidins), which alter the color, aroma, astringency, and antioxidant properties of fruit ( $\mathrm{He}$ and Glusti, 2010) Importantly, light can have dramatic effects upon the quantity and types of flavonoids that accumulate (reviewed (Zoratti et al., 2014) although it should be noted that centuries of selective breeding have altered the specific responses of our crops (for example red vs. green apples Feng et al., 2013). Light has been observed to affect carotenoid biosynthesis in a number of species during fruit ripening and flower development (Giovannoni, 2004; Adam- Phillips, 2004). It is evident in the reviewed literature of Iliac et al. (2017) that light quality influences the biosynthesis, accumulation and retention of vegetable phytochemicals, as well as the decay development during storage.

\subsection{Effect of light interception and distribution}

The fruit yield is related to light interception, whereas fruit quality is a function of light distribution. Light interception is influenced by plant density, canopy shape, canopy leaf area index and can be raised by increasing the density of foliage in the canopy, the height of the tree and number of trees per hectare. Light intensity decreases, within the tree canopy as the outer portion shades the inner canopy. Light exposure influences flower bud differentiation, fruit set, fruit colour and quality. Approximately $30 \%$ of full sunlight is required to maximize photosynthesis and initiate flower buds. The fruit quality attributes like fruit size, firmness, soluble solids (sweetness) are increased under high light conditions and are decreased in deeply shaded areas of the tree canopy. At least $50-60 \%$ of full sunlight is required for fruits to develop and acquiring maximum red colour particularly for tropical and sub-tropical fruit crops. In case of litchi, during reproductive phase, mostly the value of PAR is $>700$ and westerly winds during this period causes maximum fruit drop, sun burning and cracking due to desiccation (Singh et al., 2012). Fruit trees in general are expected to respond differently to changes in light interception, rainfall and temperature because they differ widely with respect to adaptations to seasonal drought and cues for bud break of vegetative and flower buds. The processes influencing floral initiation and bloom in litchi are elucidated by Davenport (2000) through a model proposing reproductive induction by vegetative and floral promoters (phytohormones) governing the type of shoot initiation, which is very much influenced by the environment. Better fruit set, fruit development and yields occur when temperature approaches from low (restricting vegetative phase) to warmer days and nights (allowing flower development and pollination), then again the higher range for fruit development and maturity (Davenport, 2003).

Canopy management techniques that maximize light interception and distribution in orchard trees would therefore be expected to improve $\mathrm{CO}_{2}$ fixation and fruit yields in litchi. Dense litchi orchards having poor productivity due to poor light interception leads to limited flower development (Kumar, 2015). The distribution of light and leaf nitrogen within the tree is usually a good indication of potential photosynthesis. Interaction effect of light, temperature, partial pressure of $\mathrm{CO}_{2}$, water vapour and leaf water status influences photosynthesis by affecting the opening and closing of the stomata or leaf chemistry (Hieke et al., 2002). They further observed that much higher photosynthetic photon flux density (PPFDs) is required for maximum growth and photosynthesis than for survival on the forest floor.

\subsection{The light use efficiency of plants}

The PAR radiation is subdivided into various bands and the most important for plant physiological processes are blue $(400-500 \mathrm{~nm})$, green $(\mathrm{G}, 500-600 \mathrm{~nm})$ and red $(600-700 \mathrm{~nm})$ light (Nobel, 1983; Combes et al., 2000). Plants use the light in the 400 to $700 \mathrm{~nm}$ range for photosynthesis, but they make better use of some wavelengths than others. All plants show a peak of light use in the red region, approximately $650 \mathrm{~nm}$ and a smaller peak in the blue region at approximately $450 \mathrm{~nm}$. Plants are relatively inefficient at using light and are only able 
to use about a maximum of $22 \%$ of the light absorbed in the 400 to $700 \mathrm{~nm}$ region. Light use efficiency by plants depends not only on the photosynthetic efficiency of plants, but also on the efficiency of the interception of light. Light exposure is a factor that varies with the position within the canopy of the fruit-bearing branch and of the fruit itself.

\section{Management Approaches to Harness Light}

Light intensity, duration and quality (sunlight spectrum) management promises to provide a new technological alternative for sustainable production in horticultural crops. However, little information exists on light quality management in fruit crops. Global climate change may force variation in timing, duration and synchronization of phenological events in fruit crops. Cloudy weather during fruit set and development causes poor fruit set, heavy fruit drop and delayed colour development in litchi. Now evidences are available to show that significant variation (advanced or delayed) in onset dates of flowering and fruiting responses do exist in different fruit trees as a result of climatic change. Perennial fruit orchards do offer great potential for modification of light and temperature environments within canopies by pruning, training, tree size, row spacing and row orientation. More recently; there are some tools/ practices which can manipulate the light quality specifically for plant development and growth as well as quality production. These are: use of reflective films that improves UV and red light properties, colour shed net (black, blue, green, red, white) and bagging of fruit bunches. The concepts involved in the optimization of environment for quality production is to maximize the photosynthetic process in the plant. Therefore, on-going modifications are made to harness the maximum available natural resources to match the maximum rate of photosynthesis so that we can get more quality production. This implies that growers can direct the results of photosynthesis, the production of assimilates, sugars and starches, towards both vegetative and generative in a balance.

\subsection{Canopy management}

Light distribution in the canopy is not only influenced by the direction of the light or the fraction of diffused or direct light incident on the canopy, but also depends on crop architecture. Sarlikioti et al. (2011a, b) indicated that plant architecture has a large impact on crop light distribution and photosynthesis. Many studies suggest that plants use diffused light more efficiently than direct light, and this is mainly attributed to a more uniform light distribution in the canopy (Gu et al., 2003; Alton et al., 2007; Mercado et al., 2009).The canopy microclimate is specific plant growth environment and is the climate conditions in the leaf canopy after filtration by the "environment-plant or organ" (Zhang, 1993).The differences in fruit quality within the canopy are due to environmental light filtrating by the branch and leaves, which make up canopy structure. Kumar (2012) reported that pruned tree had given higher percentage of healthy panicles, flowering, and fruit set as compare to un-pruned litchi tree. They further observed that maximum fruited panicle appeared at middle portion of the outer canopy than the top and lower, hence, the technique of centre opening as well as non selective pruning should be adopted to reduce the height and enhance the canopy spread. Léchaudel et al. (2013) stated that high light exposure conditions in the canopy might induce metabolic and physiological disorders in mango fruit. Feng et al. (2013) concluded that the anthocyanin content in apple fruit exposed to sunlight was higher than in shaded fruit. Proietti et al. (2015) found that in olive light distribution in the canopy changes in olive cultivars Arbequina, Leccino and Maurino and this could be one of the reasons for the higher production efficiency (amount of production per unit of leaf area) in Maurino compared to the other cultivars.

The spatial distribution of canopy structure within the canopy has both horizontal and vertical structures. The horizontal structure usually has a significant effect on the quality of the fruit developing in the inner and outer canopy. For example, the levels of anthocyanin and flavonoids were significantly higher in the apple fruit developing in the outer canopy than in inner canopy fruit regardless of the canopy cover (Ju et al., 1999). Feng et al. (2013) found that the fresh weight and soluble solid content in three different apple cultivars were all higher in the outer canopy fruit than in the inner canopy fruit. The vertical extent of the canopy mainly affects the lower, middle and top levels. Tyas et al. (1998) also came to a similar conclusion for "Tai So" lychee.

\subsection{Use of reflective films as mulches}

Reflective mulches are able to change major environmental parameters, specifically the light-environment at the tree canopy level. The use of reflective ground cover materials such as white woven plastics, aluminum foil, lime and biodegradable white paint is a good approach for improvement the light use in orchard systems (Ju et al., 1999; Whiting et al., 2008, and Blanke, 2007). The main effect of reflective film is the increases of PAR reflection by reflecting light incoming to floor back into the tree canopy, improving widely the light availability to shading parts of the tree canopy (Widmer et al., 2001). Layne et al., 2001, conducted experiment with high density polyethylene mulch, characterized by having a reflective metalized surface, on peach cultivars selected for their poor red colouration, showed significant increases in red colour, especially on fruit from the lower part of the canopy. Reflective mulch (Extenday Europe Ltd., Egham, UK) was laid down on both sides of the inter-row of half of the trees (Figure 1). Apart from improving the PAR, the reflective film increases significantly the UV light and red light component of sunlight. Indeed different reports have shown that reflection of UV light by reflective films was up to $80 \%$ of light incoming to orchard floor (Ju et al., 1999; Blanke, 2007). Such type of practices can also be applied in case of litchi as lower canopy fruits are less bright red in colour. 


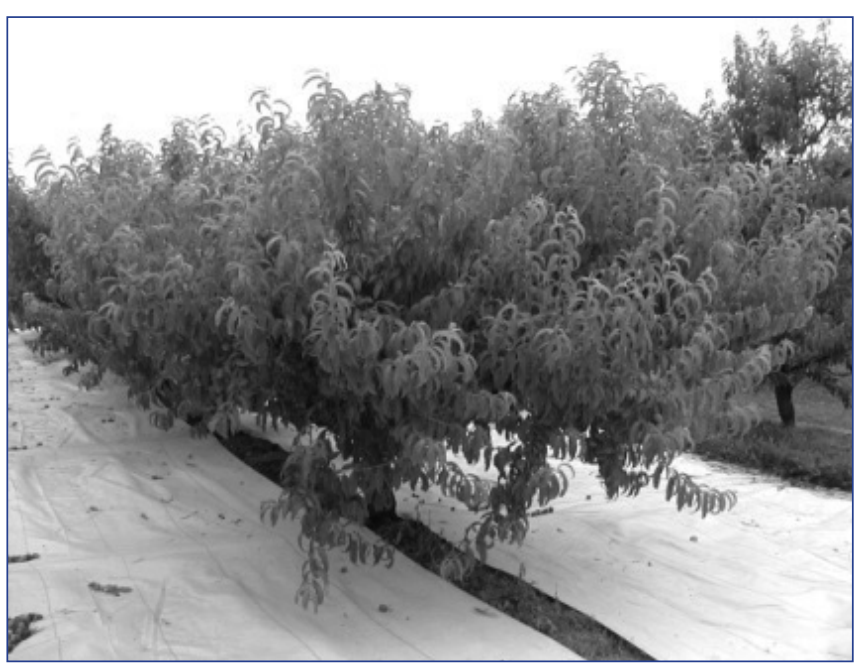

Figure 1: Use of reflective film in peach adopted from Layne et al., 2001.

\subsection{Use of shade net}

Shade net can provide physical protection (birds, hail, insects, excessive radiation), affect environmental modification (humidity, shade, temperature), and increase the relative proportion of diffused (scattered) light as well as absorb various spectral bands, thereby affecting light quality. Nettings, regardless of color, reduce radiation reaching crops underneath. Obviously, the higher the shade factor, the more radiation will be blocked. Reductions in radiation resulting from netting will affect temperatures (air, plant, soil) and relative humidity. Besides affecting the amount of radiation, nettings can influence the radiation direction. These effects can influence crops as well as the organisms associated with them. Roygrong et al. (2007) in their study observed that the percent of flowering was negatively affected by shading. In the beginning of flowering (January) the flowering rate was $13 \%$ and $42 \%$ for shaded and non shaded parts, respectively. There was only $44 \%$ of flowering in the shaded treatment, which was significantly less as compared to the non-shaded treatment with an average flowering of around $72 \%$. The results indicated that long term shading with $50 \%$ light reduction strongly effected on flowering of litchi (Table 1). Based on these results, an interaction between light supply and flower induction is obvious. Two effects could be responsible: Either the high light intensity exerts photo reactive stress, promoting hormonal reactions of the tree, which leads to flower induction. Or the temperature under the shading material during the flower inducing time could be higher due to less airflow, resulting in the absence of

\begin{tabular}{llc}
\hline Table 1: Effect of shed net on flowering & \\
\hline \multirow{2}{*}{ Time of Flowering } & \multicolumn{3}{c}{ Percentage of flowering (\%) } \\
\cline { 2 - 3 } & Shading & Non-shading \\
\hline January & $13 \pm 17 \mathrm{a}$ & $42 \pm 19 \mathrm{~b}$ \\
February & $44 \pm 11 \mathrm{a}$ & $72 \pm 17 \mathrm{~b} \mathrm{~F}$ \\
\hline
\end{tabular}

flower induction.

Percentage of flowering was evaluate in both shaded and nonshaded parts at the beginning of flowering (January) until at late flowering (mid of February). Values with different letters indicate statistically significant differences at $\mathrm{P}=0.05$ Adopted from Roygrong et al. 2007.

Ilic et al. (2012) reported that changing the light intensity and radiation spectrum (red and pearl nets with $40 \%$ shade) has a large impact on the total production and tomato fruit quality. Shading reduced the appearance of tomato physiological disorders, increased the marketable tomato production by about 35\% compared to non-shading conditions.

\subsubsection{Photo-selectivity}

Colour nets represent a new agro-technological concept, which aims at combining the physical protection together with differential filtration of the solar radiation. Studies of several crops grown under various coloured shade nets of the $50-80 \%$ shade, yielded high as compared to open field conditions (Shahak et al., 2004). Published literature supports the view that coloured nets helps in improving canopy vitality, photosynthesis, improved fruit set, fruit size and extended harvest season (Meena et al., 2016). Ilic and Fallik (2017) reported that modification of spectral quality via coloured shade nets can act as a physiological tool to modify the crop microenvironment and advance plant growth and yield.

Colored shade nets are being intensively tested primarily because of their ability to manipulate the spectra of radiation reaching the crops below (Figure 2). They can be used to change red to far-red light ratios that are detected by phytochromes, the amounts of radiation available to activate the blue/ultraviolet-A photoreceptors, blue light involved in phototropic responses mediated by phototropins, and

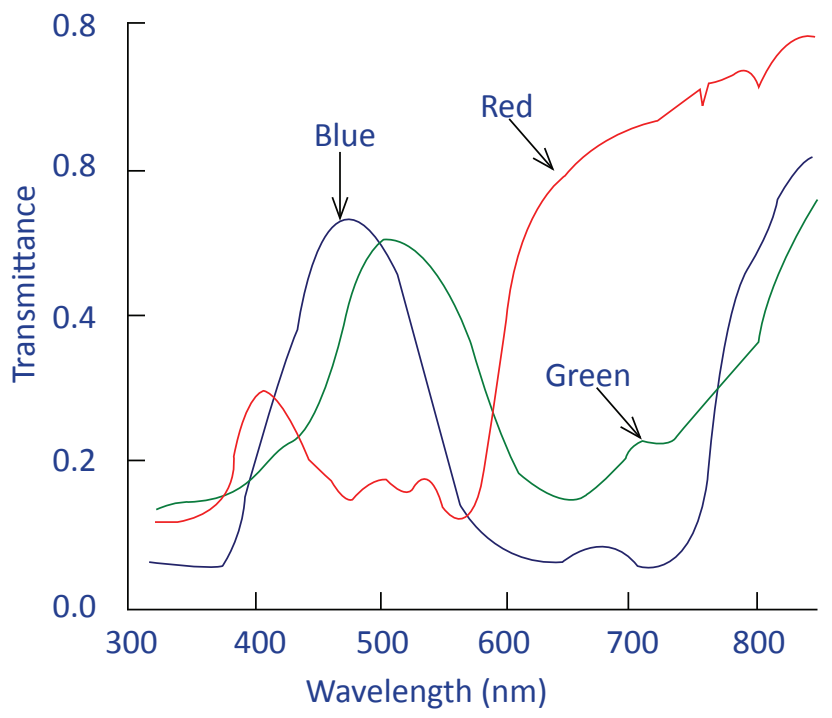

Figure 2: Spectra of transmittance for three compared with no net colored shade nets (adopted from Oren-Shamir et al., 2001). 
radiation at other wavelengths that can influence plant growth and development. Meena et al. (2016) demonstrated the potency of photo-selective netting (red colour) for improving the agro-economic performance of horticultural crops especially in harsh climates and arid zones. Placing the red nets over mature plants of pomegranate at intermediate shade levels (35\% PAR and 50\% PAR) provided higher yield without any detrimental effects on fruit quality. Colored netting was also shown to affect the rate of fruit maturation with light scattering nets (pearl, white) increasing the rate of maturation of a number of cultivars and black and red nets delaying the maturation of 'Red Globe'. With blue netting, maturation was advanced for Superior but delayed for Perlette (Shahak et al., 2008). Similarly in pear, kiwi fruit, pepper, mango, grape etc the effects of different shed net are varied and plant responses may differ even among cultivars of the same plant. Therefore, much additional research is needed to demonstrate and elucidate the effects of colored shade nets. Because colored netting has numerous effects besides photoselective ones and even photo selectivity can change over time. Radiation quality and quantity values and microclimate parameters should be measured and reported to aid in the determination of which factors might be causing any reported results.

A study was conducted at ICAR-NRC on Litchi, Muzaffarpur, Bihar where the litchi trees were covered 20 to 25 days after fruit set with shade net (white and green ) with two shading percentages ( 30 and $50 \%$ ) and an uncovered control comprising of 9 treatment combinations in total. The results showed that irrespective of colour and percent shading, shade nets had a significant effect on increase in fruit weight, percentage of Class I fruits, reduced percentage of discarded fruits and extended the harvesting period in comparison to control (uncovered). Shade net treatments resulted in about $50 \%$ higher fruit retention and almost $40 \%$ less sunburned and cracked fruits and also extended the harvesting period by almost 7 to 12 days compared to open trees (Anonymous, 2014). Similarly Shahak et al. (2004) found that a red/ white shade net treatment that reduced PAR by $18 \%$ increased fruit set of apple cultivar Smoothee Golden Delicious (SGD) compared with the no-net control. It was further observed that all the shade nets except white improved the midseason red coloration (coverage and intensity) of Topred delicious. Berry and cluster weights of cultivar Superior were increased most under $30 \%$ yellow nets, but $30 \%$ gray reduced yields compared with the no-net control. Yields were also increased under $30 \%$ black, $30 \%$ red, and $22 \%$ white nets. In other trials using Red Globe as the cultivar, Stamps (2008) reported increased berry size under the $30 \%$ yellow compared with five other colored nets and increased berry weight under black, red, and white netting compared with no net. The use of shading nets has become very popular in Serbia in the last two years due to the very high temperatures $\left(35-40^{\circ} \mathrm{C}\right)$ in the summer season Ilic et al., 2012). High temperatures during the growing season have been reported to be detrimental to growth, reproductive development and yield of tomato
(Saeed et al., 2007).

\subsubsection{Radiation scattering}

Diffused light has been shown to increase radiation use efficiency, yields (both at the plant and ecosystem level), and even be a factor affecting plant flowering (timing and amounts). Any shade netting can scatter radiation, especially ultraviolet because netting is usually made using ultravioletresistant plastic. Shade netting that increases light scattering but does not affect the light spectrum has been shown to increase branching, plant compactness, and the number of flowers per plant. Colored shade nets can also increase light scattering by $50 \%$ or more (Figure 3 ) and this alone may influence plant development and growth.

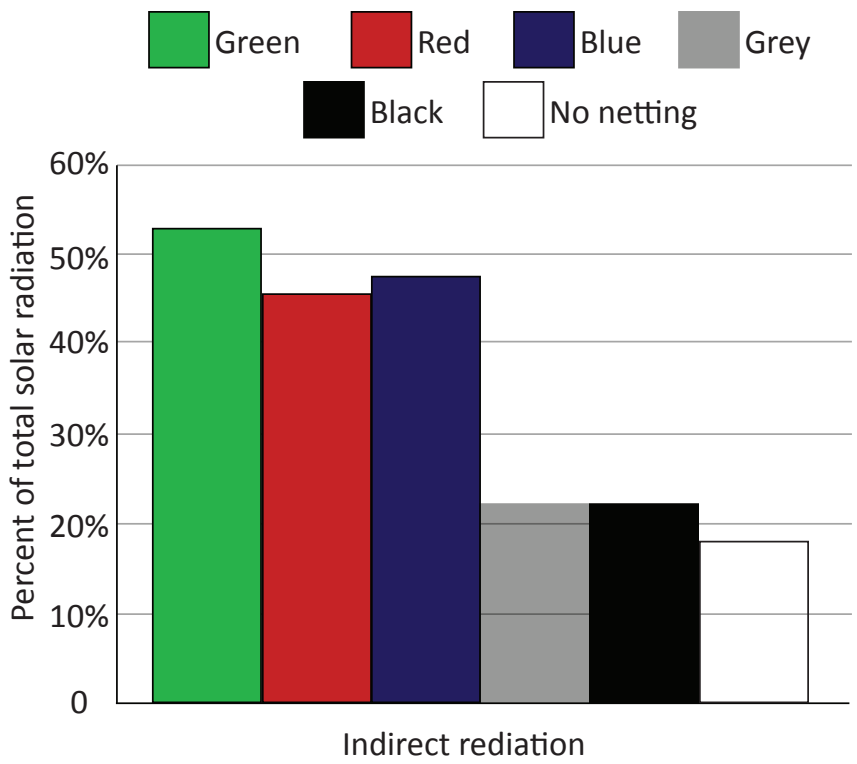

Figure 3: Light scattering under colored shade nets (adopted fom Oren-Shamir et al., 2001.

\subsubsection{Air movement}

Nettings also reduce wind speeds and wind run, which can affect temperatures, relative humidity, and gas concentrations resulting from reductions in air mixing. These changes can affect transpiration, photosynthesis, respiration, and other processes. The effects on air movement depend on the porosity and physical location of the netting in relation to the plants and can be affected by time of day, season, and other factors. It protects litchi fruit from hot westerly wind which causes huge sunburn and cracking (Purbey and Kumar, 2015).

\section{Bagging of Fruit Bunches}

The fruit bagging technique is widely adopted in the production of apple, pear, grapefruit, litchi, longan and other fruits, for improving fruit quality and reducing pesticide residues effectively, preventing from rust, decreasing rates of insect or disease damaged fruit and cracking fruit. The effects of bagging were different from fruit trees. It is a physical protection technique commonly applied to many fruits, 
which not only improves fruit visual quality by promoting fruit colouration but also enhances internal fruit quality. Preharvest bagging of fruits has been conventionally practiced for fruit growing in Japan, Australia and China as well as in peach, apple, pear, grape and loquat cultivation in order to optimize fruit quality and for improving fruit coloration to increase their market value (Table 2).

Several authors have reported contradictory results for the effects of pre-harvest bagging on fruit size, maturity, peel color, flesh mineral content and fruit quality, which may be due to differences in the type of bag used, the stage of fruit development when it was bagged, duration of fruit exposure to natural light after bag removal (before harvesting), and/ or

\begin{tabular}{|c|c|c|}
\hline Fruit & Bagging & Reference \\
\hline Apple & $\begin{array}{l}\text { Yellow colour non woven PP } \\
\text { bags at } 45-60 \text { days before } \\
\text { harvesting }\end{array}$ & $\begin{array}{l}\text { Sharma, et al. } \\
2013\end{array}$ \\
\hline Banana & $\begin{array}{l}\text { Blue polyethylene }(0.5 \mathrm{~mm} \\
\text { thick) sleeves at } 15 \text { days } \\
\text { prior to harvesting }\end{array}$ & Berrill, 1956 \\
\hline Peach & $\begin{array}{l}\text { Bagged with single layer of } \\
\text { orange paper, } 27 \% \text { of light } \\
\text { transmittance, at } 50 \text { DAFB } \\
\text { until the harvest time. }\end{array}$ & Li, et al, 2006 \\
\hline Guava & $\begin{array}{l}\text { Waxed paper bag/ plastic } \\
\text { bag } 1 \text { month before har- } \\
\text { vesting }\end{array}$ & Singh, et al. 2007 \\
\hline Litchi & $\begin{array}{l}\text { White colour non woven } \\
\text { PP bags/ butter paper bags } \\
\text { at } 20-30 \text { days before har- } \\
\text { vesting }\end{array}$ & $\begin{array}{l}\text { Purbey and Ku- } \\
\text { mar, } 2015\end{array}$ \\
\hline
\end{tabular}

fruit- and cultivar-specific responses. Bagged fruits are capable of synthesizing anthocyanin when they were exposed to light for few days before the actual date of harvest. It is believed that bagging increases light sensitivity of fruit and stimulates more anthocyanin synthesis when fruits are kept in WBPB and $\mathrm{MCB}$ ( 59.16 and $61.38 \%$ photo-permeability respectively) than fruit kept in BPB (3.90\% photo-permeability) during maturation, which indicates medium light intensity could be imperative for anthocyanin synthesis. A study conducted at ICAR-NRC on Litchi, Muzaffarpur showed that litchi fruit bunches when bagged 25-30 days before expected harvesting with non-woven PP bag (White) there was $25-30 \%$ less damaged fruits due to sun burning and cracking in comparison to control (Purbey and Kumar, 2015). It was also found that fruits were 80-90 percent less borer infested as compare to unbagged fruits. Bagged fruits produced comparatively heavy and big size fruits with 9-19\% more weight over unbagged fruits with more bright red color. Li et al. (2006) reported that too high or too low intensity of light exposure did not favor the formation of $\gamma$-decalactone and other lactones in 'Hujingmilu' peaches. Li et al. (2006) also indicate that too high or too low intensity of light exposure did not favor the formation of $\gamma$-decalactone and other lactones in 'Hujingmilu' peaches. They further concluded that high quality 'Hujingmilu' peaches with abundant aromas can be produced when bagged with single layer of orange paper, $27 \%$ of light transmittance, at 50 DAFB until the harvest time. Management of tree canopy and structure for efficient adoption of bagging technique is essentially required. Zhang et al. (2016) observed that the litchi pericarp gradually turned red as the fruits matured under natural conditions; by contrast, the pericarp remained light green under shaded conditions and rapidly became red after the fruits were exposed to light. These phenomena were consistent with the changes in the abundance of anthocyanins in the pericarps. In general, anthocyanin contents gradually increase during natural coloration. In this study, anthocyanins were not detected in the pericarp under shaded conditions. After the fruits were exposed to light, the anthocyanin contents increased remarkably within 1 week (Figure 4 a,b). These results suggested that light is essential for anthocyanin biosynthesis in litchi pericarp. However, the mechanism of light- induced anthocyanin biosynthesis remains unknown.
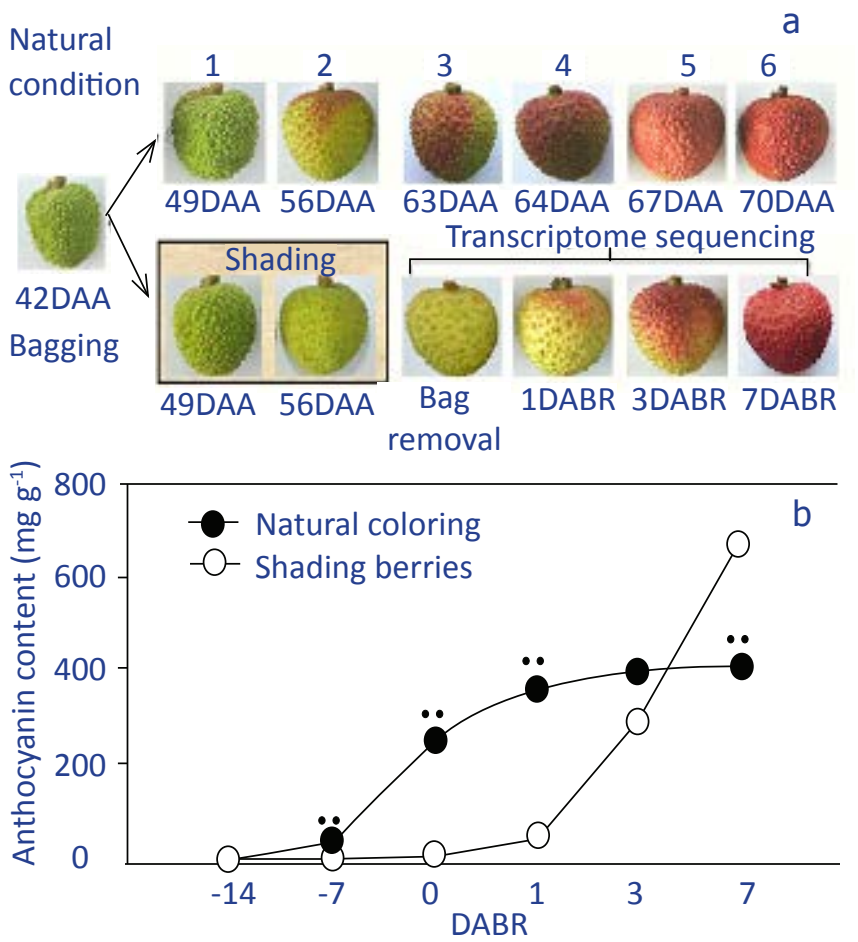

Figure 4: Color and anthocyanin content of litchi pericarp. (A) Images of litchi fruits in different coloration stages under natural conditions, shading and exposure. Samples corresponding to the developmental stages at $0,1,3$, and 7 days after bags were removed were selected for transcriptome sequencing.

(B) Total anthocyanin contents in the pericarp indifferent coloration stages. Vertical bars represent the standard error of three biological replicates. ${ }^{* * \prime}$ represents significantly differences at the level of $p<0.01$. Adopted from Zhang et al. 2016 


\section{Conclusion}

Environmental factors are the main sources of variation of fruit quality. Litchi is highly sensitive to change in climatic condition and selective to the environmental factors. An integrated approach of canopy management along with practices/ designs like use of shed nets, bagging of fruit bunch has been found effective to manipulate the environmental factors especially light for quality litchi fruit production. However, more intensive study is required for understanding the physiological mechanisms behind the plant responses.

\section{Acknowledgment}

This work was supported by ICAR-NRC on Litchi, Muzaffarpur, Bihar.

\section{References}

Adams-Phillips, L., Barry, C., Giovannoni, J., 2004. Signal transduction systems regulating fruit ripening. Trends Plant Sci. 9, 331-338.

Alton, P.B., North, P.R., Los, S.O., 2007. The impact of diffuse sunlight on canopy light-use efficiency, gross photosynthetic product and net ecosystem exchange in three forest biomes. Global Change Biology 13, 776-787.

Anonymous, 2014. Extending the harvesting period of litchi. In AICRP on fruits, Research report, 107, 259.

Batein, D.J., Lahav, E., 1981. The effect of temperature on growth and nutrient uptake in three litchi varieties. Research Report of the Tropical Fruit Research Station, Alstonville, N.S.W., 37-38.

Batschauer, A., 1999. Light perception in higher Plants. Cellular and Molecular Life Science 55, 153-166.

Berrill, F.W., 1956. Bunch covers for banana. Queensland Agricultural Journal 82(8), 435-440.

Blanke, M., 2007. Alternatives to reflective mulch cloth (Extenday ${ }^{\circledR}$ )? Scientia Horticulturae 116, 223-226.

Cerny, T.A., Faust, J.E., Layne, D.R., Rajapakse, N.C., 2003. Influence of photoselective films and growing season on stem growth and flowering of six plant species. Journal of the American Society for Horticultural Science 128, 486-491.

Combes, D., Sinoquet, H., Varlet-Grancher, C., 2000. Preliminary measurement and simulation of the spatial distribution of the Morphogenetically Active Radiation (MAR) within an isolated tree canopy. Annals of Forest Science 57, 497-511.

Davenport, T.L., 2000. The processes influencing floral initiation and bloom in litchi; the role of phytohormones in a conceptual flowering model. Horticulture Technology 10, 733-739

Davenport, T.L., 2003. Management of flowering in three tropical and subtropical fruit tree species. Horticultural Science 38, 1331-1335
Eschenbach, C., Glauner, R., Kleine, M., Kappen, L., 1998. Photosynthesis rates of selected tree species in lowland Dipterocarp rainforest of Sabah, Malaysia. Trees 12, 356-365.

Feng, F., Li, M., Ma, F., Cheng, L., 2013. Phenylpropanoid metabolites and expression of key genes involved in anthocyanin biosynthesis in the shaded peel of apple fruit in response to sun exposure. Plant Physiology and Biochemistry 69, 54-61. http://dx.doi.org/10. 1016/j. plaphy.2013.04.020.

Folta, K.M., Maruhnich, S.A., 2007. Green light: A signal to slow down or stop. Journal of Experimental Botany 58, 3099-3111.

Fujii, Y., Tanaka, H., Konno, N., Ogasawara, Y., Hamashima, N., Tamura, S., Hasegawa, S., Hayasaki, Y., Okajima, K., and Kodama, Y., 2017. Phototropin perceives temperature based on the lifetime of its photoactivated state. Proc. National Academy of Science, USA 114, 9206-9211.

Giovannoni, J.J., 2004. Genetic regulation of fruit development and ripening. Plant Cell 16, (S170-180).

Gu, L., Baldocchi, D.D.,Verma, S.B., 2003. Advantages of diffuse radiation for terrestrial ecosystem productivity. Journal of Geophysical Research 107, 2-1-2-23.

He, J., Giusti, M.M., 2010. Anthocyanins: natural colorants with health-promoting properties. Annual Review Food Science and Technology 1, 163-187-104

Hieke, S., Menzel, C. M., Ludders, P., 2002. Effects of light availability on leaf gas exchange and expansion in lychee (Litchi chinensis). Tree Physiology 22, 1249-1256.

Ilic, Z.S., Fallik, E., 2017. Light quality manipulation improves vegetable quality at harvest and postharvest: A review. Environmental and Experimental Botany 139, 79-90.

Ilias, I.F., Rajapakse, N.C., 2005.The effect of end -of- theday red and far-red light on growth and flowering of Petunia x hybrid 'Count- down Burgundy' grown under photoselective films. HortScience 40, 13-133.

Ilic, Z. S., Milenković, L., Stanojević, L., Cvetković, D., Fallik, E., 2012. Effects of the modification of light intensity by color shade nets on yield and quality of tomato fruits. Sci. Hortic. (Amsterdam) 139, 90-95 http://dx.doi. org/10.1016/j.scienta.2012.03.009.

IPCC, 2018. Climate change 2018: Assessment report of the intergovernmental panel on climate change (IPCC), WMO, UNEP.

Ilić, Z.S., Milenković, L., Sunić, L., 2016. Photo-selective netting for improved performance of tomato fruit. Acta Hortic. 1142. 261-267. DOI 10.17660/ActaHortic.2016.1142.40

Jackson, J.E., 1980. Light interception and utilization by orchard systems. Horticultural Reviews 2, 208-267.

Ju, Z., Duan, Y., Ju, Z., 1999. Effects of covering the orchard floor with reflecting films on pigment accumulation and fruit coloration in Fuji' apples. Scientia Horticulturae 82(1), 47-56. http://dx.doi.org/10.1016/S03044238(99)00038-2. 
Jung, J.H., Domijan, M., Klose, C., Biswas, S., Ezer, D., Gao, M., Khattak, A.K., Box, M.S., Charoensawan, V., Cortijo, S., Kumar, M., Grant, A., Locke, J.C., Schafer, E., Jaeger, K.E., Wigge, P.A., 2016. Phytochromes function as thermosensors in Arabidopsis. Science 354, 886-889.

Kambalapally, V., Rajapakse, N.C., 1998. Spectral filters affect growth, flowering, and post-harvest quality of Easter Lilies. HortScience 33, 1028-1029.

Kumar, R., 2012. ChhatrakPrabandhan in litchi-A technical bulletin, pb. ICAR-NRC on Litchi, Muzaffarpur, Bihar.

Kumar, R., 2015. Climatic issues affecting sustainable litchi (Litchi chinensis Sonn.). In: Climate dynamics in horticultural science- Impact, Adaptation, and Mitigation, (Eds. Choudhary et al.). Published by Apple Academic Press of CRC Press Group, Vol.2, 95-110.

Kumar, R., Kumar, V., 2016. Physiological disorders in perennial woody tropical and subtropical fruit crops: A review. Indian Journal of Agricultural Sciences 86(6), 703-17.

Kumar, R., Nath, V., 2013. Climate Resilient Adaptation Strategies for Litchi Production. In Climate-Resilient Horticulture: Adaptation and Mitigation Strategies (Eds. Singh et al.), pb. Springer, New Delhi, India. ISBN 97881-322-0973-7 ISBN 978-81-322-0974-4 (eBook) DOI 10.1007/978-81-322-0974-4.

Kumar, V., Purbey, S.K., Anal, A.K.D., 2016. Losses in litchi at various stages of supply chain and changes in fruit quality parameters. Crop Protection 79, 97-104. doi:10.1016/ j.cropro.2015.10.014.

Layne, D., 2001. Tree fruit reflective film improves red skin coloration and advances maturity in peach. Horticulture Technology 11, 234-242.

Lechaudel, M., Lopez-Lauri, F., Vidal, V., Sallanon, H., Joas, J., 2013. Response of the physiological parameters of mango fruit (transpiration, water relations and antioxidant system) to its light and temperature environment. Journal of Plant Physiology 170(6), 567576. http://dx.doi.org/10.1016/j.jplph.2012.11.009.

Leduc, N., Roman, H., Barbier, F., Peron, T., Thelier, L.H., Lothier, J., Mainard, S.D., Sakr, S., 2014. Light signaling in bud outgrowth and branching in plants. Plants 3 , 223-250.

Legris, M., Klose, C., Burgie, E.S., Rojas, C.C., Neme, M., Hiltbrunner, A., Wigge, P. A., Schafer, E., Vierstra, R. D., Casal, J.J., 2016. Phytochrome B integrates light and temperature signals in Arabidopsis. Science 354, 897-900.

Li, B., Jia, H.J., Zhang, X.M., 2006. Effects of fruit pre-harvest bagging on fruit quality of peach (Prunuspersica Batsch cv. Hujingmilu). Journal of Plant Physiology and Molecular Biology 32 (3), 280-286.

Li, J.A., He, Z.X., Sun, Y., Lv, F.D., Hu, F.M., Yang, W., Liu, R., Al, Gao, Chen, Z.W., Chen, Y., Liao, F., 2010. Study of photosynthetic characteristics in Camellia oleifera stand. Journal of Central South University For Technology
30(10), 56-61. http://dx.doi.org/10.14067/j.cnki. 1673923x.2010.10.015.

Mercado, L.M., Bellouin, N., Sitch, S., 2009. Impact of changes in diffuse radiation on the global land carbon sink. Nature 458, 1014-1017.

Menzel, C.M., 1983. The control of floral initiation in lychee: a review. Scientia Horticulturae 21, 201-15.

Menzel, C. M., Simpson, D.R., 1988. Effect of temperature on growth and flowering of litchi (Litchi chinensis Sonn.) cultivars. Journal of Horticultural Science 63(2), 349-360.

Menzel, C.M., Waite, G.K., 2005. Litchi and Longan: Botany, Production and Uses. CABI Publishing, Wallingford, Oxfordshire, UK.

Meena, V.S., Kashyap, P., Nagare, D.D., Singh, J., 2016. Effect of coloured shade nets on yield and quality of pomegranate (Punica granatum) cv. Mridula in semi-arid region of Punjab. Indian Journal of Agriculture Sciences 86(4), 500-505.

Mitra, S.K., Dutta, Ray, S.K., Mandal, D., 2014. Control of fruit cracking and sun-burning in litchi by irrigation and moisture conservation. ActaHorticulturae, 1024, 177-81.

Nobel, P.S., 1983. Biophysical plant physiology and ecology. 608 p. W.H. Freeman, New York, USA.

Oren-Shamir, M., Gussakovsky, E.E., Shpiegel, E., NissimLevi, A., Ratner, K., Ovadia, R., Giller, Y.E., Shahak, Y., 2001. Coloured shade nets can improve the yield and quality of green decorative branches of Pittosporum variegatum. Journal of Horticultural Science and Biotechnology 76, 353-361.

Palmer, J.W., 2011. Changing concept of efficiency in orchard systems. Acta Horticulturae 903, 41-50.

Proietti, P., Nasini, L., Reale, L., Caruso, T., Ferranti, F., 2015. Productive and vegetative behavior of olive cultivars in super high-density olive grove. Sci. Agriculture 72 (1), 20-27. http://dx.doi.org/10.1590/0103-9016-20140037.

Purbey, S.K., Kumar, A., 2015. Effect of Pre-harvest bagging on quality and yield of litchi (Litchi chinensis Sonn) Fruits. The Ecoscan VII (Special issue), 197-201.

Ramos, J., Grace, J., 1990. The effects of shade on the gas exchange of seedlings of four tropical trees from Mexico. Funct. Ecology 4, 667-677.

Riddoch, I., Lehto,T.,Grace,J., 1991. Photosynthesis of tropical tree seedlings in relation to light and nutrient supply. New Phytology 119, 137-147.

Roygrong, S., Spreer, W., Alongkorn, W.W., Sruamsiri, T.M., Romheld, V., 2007. Partial canopy shadding as a remedy of leaf chlorosis and its influence on flowering of lychee. In conference on International agricultural research for development, University of Kassel-Witzenhausen and University of Gottingen.

Saeed, A.K., Hayat, A., Khan, A., Iqbal, S., 2007. Heat tolerance studies in tomato (Lycopersicon esculentum Mill.). 
International Journal of Agriculture and Biology 9, 649-652.

Sarlikioti, V., de Visser, P.H., Marcelis, L.F.M., 2011a. Exploring the spatial distribution of light interception and photosynthesis of canopies by means of a functionalstructural plant model. Annals of Botany 107, 875-883.

Sarlikioti, V., de Visser, P.H., Buck-Sorlin, G.H., Marcelis, L.F.M., 2011b. Howplant architecture affects light absorption and photosynthesis in tomato: towards an ideotype for plant architecture using a functional-structural plant model. Annals of Botany 108, 1065-1073.

Shahak, Y., Gussakovsky, E.E., Gal, E., Ganelevin, R., 2004. Color Nets: Crop protection and light quality manipulation in one technology. Acta Horticulture 659, 143-151.

Shahak, Y., Gussakovsky, E.E., Cohen, Y., Lurie, S., Stern, R., Kfir, S., Naor, A., Atzmon, I., Doron, I., Greenblat-Avron, Y., 2004. ColorNets: A new approach for light manipulation in fruit trees. Acta Horticulturae 636, 609-616.

Shahak, Y., Ratner, K., Giller, Y.E., Zur, N., Or, E., Gussakovsky, E. E., Stern, R., Sarig, P., Raban, E., Harcavi, E., Doron, I., Greenblat, A.Y., 2008. Improving solar energy utilization, productivity and fruit quality in orchards and vineyards by photoselective netting. ActaHorticulturae 772, 65-72.

Sharma, R.R., Pal, R.K., Asrey, R., Sagarl, V.R., Dhiman, M.R., Rana, M.R., 2013. Pre-harvest fruit bagging influences fruit color and quality of apple cv. Delicious. Agricultural Sciences 4(9), 443-448. http://dx.doi.org/10.4236/ as.2013.49059

Singh, B.P., Singh. R.A., Singh, G., Killadi, B., 2007. Response of bagging on maturity, ripening and storage behaviour of winter guava. Acta Horticulturae 735, 597-601.

Singh, G., Nath, V., Purbey, S.K., Singh, S.K., Pal, R.K., 2012. Post Harvest Handling and valorizations of Litchi Fruits, FAO Bulletin, published by National Research Centre on Litchi, Muzaffarpur, Bihar, 1-30.

Smith, H., 1982. Light quality, photoreception, and plant strategy. Ann. Rev. Plant Physiology 33, 481-518.

Stamps, R.H., 2008. Differential effects of colored shade nets on three cut foliage crops. Acta Horticulturae 770, 169-176.

Thompson, W.A., Stocker, G.C., Kriedemann, P.E., 1988. Growth and photosynthetic response to light and nutrients of Flindersia brayleyana F. Muell., a rainforest tree with broad tolerance to sun and shade. Australian Journal of Plant Physiology 15, 299-315.

Thompson, W.A., Kriedemann, P.E., Craig, I.E., 1992.
Photosynthetic response to light and nutrients in suntolerant and shade tolerant rainforest trees. I. Growth, leaf anatomy and nutrient content. Australian Journal of Plant Physiology 19, 1-18.

Turner, D.W., 1994. Bananas and plantains. In: Schaffer, B.S., Andersen, P.C. (Eds.), The Handbook of Environmental Physiology of Fruit Crops. Vol. II. Subtropical and Tropical Crops. . CRC Press, Boca Raton, FL, 37-64.

Tyas, J.A., Hofman, P.J., Underhill, S.J., Bell, K.L., 1998. Fruit canopy position and panicle bagging affects yield and quality of Tai So' lychee. Scientia Horticulture 72(3), 203-213. http://dx.doi.org/10.1016/S03044238(97)00125-8.

Whitelam, G.C., Halliday, K.J., 2007. Light and Plant Development. Annual Plant Reviews 30 (Blackwell Publishing, UK,).

Whiting, M.D., Rodriguez, C., Toye, J., 2008. Preliminary testing of reflective ground cover: Sweet cherry growth, yield and fruit quality. Acta Horticulturae 795, 557-560.

Widmer, A., Stadler, W., Krebs, C., 2001. Bessere Fruchtqualität mit weisser, lichtreflektierender Bondenfolie? Schweizerischen Zeitschrift für Obst- und Weinbau 17, 470-473.

Wiebel, J., Chacko, E.K., Downton, W.J.S., Ludders, P., 1993. Influence of irradiance on photosynthesis, morphology and growth of mangosteen (Garcinia mangostana L.) seedlings. Tree Physiology 14, 263-274.

Yadav, P., Lal, R.L., Pandey, C., 2011. Effect of different levels of fertigation on yield, quality and leaf nutrient status of litchi (Litchi chinensis Sonn.) cv. Rose Scented. Progressive Horticulture 43(2), 276-80.

Zhang, D.P., 1993. Canopy microclimate and the basic concept and connotation in biological research regulation. SinoOverseas Grapevine Wine 2, 1-4. http://dx.doi.org/ 10.13414/j.cnki.zwpp.1993.02.001.

Zoratti, L., Sarala, M., Karppinen, K., Marteens, S., Giongo, L., Haggman, H., Jaakola, L., 2014. Monocromatic light increases anthocyanin content during fruit development in bilberry.BMC Plant Biology, 14, article number, 377.

Zhang, H.N., Li, W.C., Wang, H.C., Shi, S.Y., Shu, B., Liu, L.Q., Wei, Y.Z., Xie, J.H., 2016. Transcriptome Profiling of LightRegulated Anthocyanin Biosynthesis in the Pericarp of Litchi. Frontiers in Plant Science. doi: 10.3389/ fpls.2016.00963 